\title{
Viabilitas Biji dan Pertumbuhan Bibit Kelor (Moringa oleifera Lam.)
}

\section{Seed Viability and Growth of Moringa oleifera Lam. Seedling}

\author{
Bambang Budi Santoso* dan IGM Arya Parwata \\ Pusat Studi dan Pengembangan Pertanian Energi (Energy Farming Centre), Fakultas Pertanian, \\ UNRAM, Nusa Tenggara Barat, INDONESIA. Tel. +62-0370 621435, Fax. +62-0370 640189, \\ *email: bbsjatropha1963@gmail.com / bambang.bs@unram.ac.id
}

Manuscript received: 07-10-2017. Accepted:18-11- 2017

\begin{abstract}
ABSTRAK
Buah kelor (Moringas oleifera L.) yang secara fisik berukuran panjang dan memiliki banyak biji di dalamnya tentu akan menyebabkan perbedaan tingkat kematangan biji dan kemudian perbedaan pada viabilitas benih yang dihasilkan. Penelitian ekperimental ini terdiri atas dua percobaan, yaitu percobaan pertama bertujuan mengetahui viabilitas biji dari tiga posisi biji dalam buah dan percobaan kedua bertujuan mengetahui pertumbuhan bibit tanaman kelor hingga umur dua bulan dari masingmasing posisi biji pada buah tersebut. Hasil penelitian menunjukkan bahwa posisi biji dalam buah kelor berpengaruh nyata terhadap viabilitas benih, namun berpengaruh tidak nyata terhadap pertumbuhan bibit hingga umur dua bulan. Biji-biji pada posisi di pangkal dan tengah dari buah memiliki viabilitas lebih baik dibandingkan biji-biji pada posisi di ujung buah.
\end{abstract}

Kata kunci: berat biji, pemasakan, perkecambahan, posisi biji

\begin{abstract}
Fruits of Moringas oleifera L. is physically long and has many seeds in would certainly cause differences in seed maturity level and then difference in seed viability. This experimental research consisted of two experiments, the first experiment was aimed to find out the seed viability of the three seed positions in the fruits and the second experiment was aimed to determine the growth of the Moringa seedlings up to two months age from each seed position. The results shows that the seed position was significantly affected the viability of the seeds, but were not affected to the growth of seedlings until the age of two months. The seeds in position at the base and the middle of the fruit have better viability than the seeds in position at the end of the fruit.
\end{abstract}

Key words: germination, seed position, ripening, seed weight 


\section{PENDAHULUAN}

Moringa oleifera (Moringaceae) yang di Indonesia dikenal sebagai kelor adalah spesies asli dari Timur Tengah termasuk India, Pakistan, Bangladesh, dan juga Indonesia hingga Afghanistan (Fahey, 2005). Sedangkan oleh Muluvi et al. (1998) dikatakan bahwa tanaman ini merupakan tanaman yang berasal dari dataran India. Pada awal abad ke-20, tanaman kelor kemudian diperkenalkan di Afrika Timur, dan kemudian berkembang di berbagai daerah tropis lainnya (Foidl et al., 2001).

Tanaman kelor merupakan salah satu tanaman ajaib, tidak hanya sebagai sumber pangan, pengobatan, dan makanan ternak (Prajapati et al, 2003), tanaman ini juga dapat sebagai sumber energi alternatif bahan bakar (biodiesel) yang ramah lingkungan (Rashid et al, 2008) karena di dalam bijinya mengandung minyak 35-40\% (Rashid et al., 2008), serta mudah tumbuh di lahan kritis atau lahan kering (Anwar et al., 2007),). Tanaman kelor menjadi pilihan yang layak untuk dikembangkan sebagai sumber pangan dan juga energi. Oleh karena itu, budidaya tanaman ini diharapkan mampu menyediakan sumber bahan bakar alternatif atau substitusi, dapat meningkatkan taraf hidup dan tambahan penghasilan masyarakat (khususnya petani), dapat menanggulangi kemiskinan dan penambahan hasil devisa, dan memperbaiki lingkungan, serta sekaligus penyangga sumber pangan dan obat.

Agar dapat memanfaatkan tanaman kelor sebagai sumber pangan sehat dan sekaligus obat, serta alternatif bahan bakar minyak, maka mengenal tanaman ini lebih dekat dan sekaligus mempersiapkan teknologi budidayanya perlu menjadi perhatian. Sampai saat ini secara umum teknik budidaya tanaman kelor belum diketahui karena kurangnya perhatian terhadap tanaman ini, termasuk di dalamnya karakterisasi masing-masing tanaman yang telah tumbuh dan berkembang di berbagai daerah di Indonesia, demikian pula halnya dengan aspek pembibitan maupun pertumbuhan dan perkembangan tanaman yang tergolong tahunan (perennial).

Pengembangan tanaman kelor yang diperbanyak dengan biji akan memberikan banyak keuntungan pada produksi biomassa berupa daun (Nouman et al., 2012). Namun demikian, perkecambahan biji kelor, untuk mempersiapan bibit, sangat rendah akibat kehilangan viabilitasnya (Mbvuma at al., 2013; Nouman et al., 2012), dan selanjutnya pertumbuhan bibit tanaman kelor cukup lambat sehingga diperlukan beberapa perlakuan yang dapat mendorong pertumbuhan (Baye-Niwah and Mapongmetsem, 2014; Nouman et al., 2012).

Aspek perkecambahan biji kelor cukup banyak dilaporkan oleh para peneliti, namun tidak ada yang membahas pengaruh posisi benih dalam polong (buah) terhadap perkecambahan biji, termasuk perbenihan kelor khususnya di Nusa Tenggara Barat, Indonesia. Pada papaya dilaporkan Branco (2007) bahwa, biji yang berasal dari pangkal buah memiliki viabilitas lebih baik dibandingkan posisi lainnya. Marliah et al. (2009) menyatakan pula bahwa letak biji pada buah berpengaruh sangat nyata terhadap daya berkecambah dan kecepatan tumbuh, akan tetapi berpengaruh tidak nyata terhadap potensi tumbuh dan keserempakan tumbuh. Mereka menemukan bahwa, viabilitas benih nangka terbaik diperoleh pada biji yang terletak pada tengah buah. Namun benih berasal dari ujung buah papaya lebih baik viabilitasnya dibandingkan posisi lainnya dilaporkan Sulistyowati (2004). Sehubungan dengan buah kelor yang secara fisik berukuran panjang dan memiliki banyak biji di dalamnya, maka diduga terdapat berbedaan viabilitas biji terkait dengan posisi biji dalam 
buah. Oleh karena itu untuk keperluan perbenihan dan sekaligus mempersiapkan bibit berkualitas, maka perlu diketahui tingkat kualitas biji (benih) dari masing-masing posisinya di dalam buah. Artikel ini merupakan catatan penelitian yang memaparkan pengaruh posisi biji di dalam buah kelor terhadap kualitas viabilitas benih yang dihasilkan.

\section{BAHAN DAN METODE}

\section{Waktu, Kondisi, dan Tempat Percobaan}

Penelitian ini merupakan percobaan ekperimental yang dilakukan di nursery perbanyakan tanaman berlokasi di kota Mataram dengan ketinggian $16 \mathrm{~m} \mathrm{dpl}$, posisi geografis $8^{\circ} 34^{\prime} 47.19$ 'S $116^{\circ} 05^{\prime} 47,91^{\prime \prime}$ T. Suhu udara di lokasi saat percobaan bulan Januari, Februari, Maret, dan April 2017 yaitu 27,4 ${ }^{\circ} \mathrm{C}, 26,9{ }^{\circ} \mathrm{C}, 27,6{ }^{\circ} \mathrm{C}$, dan 27,5 ${ }^{\circ} \mathrm{C}$, kelembaban udara $84 \%, 85 \%, 83 \%, 83 \%$, dan curah hujan $152 \mathrm{~mm}, 235 \mathrm{~mm}, 159 \mathrm{~mm}$, dan $309 \mathrm{~mm}$, serta intensitas cahaya $327,9 \mathrm{Cal} / \mathrm{cm}^{2}, 363,5 \mathrm{Cal} / \mathrm{cm}^{2}, 536,6 \mathrm{Cal} / \mathrm{cm}^{2}$, dan $543,5 \mathrm{Cal} / \mathrm{cm}^{2}$.

\section{Bahan Tanaman}

Biji kelor yang digunakan merupakan biji yang diperoleh dari tanaman kelor dewasa yang telah tumbuh di halaman rumah penduduk di kawasan Kabupaten Lombok Utara, NTB (dusun Panggung, Kecamatan Kayangan) pada posisi geografis 8 $8^{\mathrm{O}} 16^{\prime} 15.02$ ''S $116^{\mathrm{O}} 17$ '34.02''T elev. $120 \mathrm{~m}$. Buah yang telah masak (berwarna coklat) dikumpulkan dari lima tegakan tanaman kelor yang tampak tumbuh paling baik dan subur. Sejumlah 100 buah diambil untuk masing-masing tanaman, dan kemudian biji-biji yang ada di dalam buah dipisahkan berdasarkan letak biji dalam buah. Pemilahan posisi letak biji dengan cara membagi sama panjang buah menjadi tiga bagian buah, sehingga letak biji dalam buah ada tiga posisi yaitu biji-biji yang berada pada pangkal dari buah, tengah dari buah, dan ujung dari buah. Setelah 2 hari dikering-anginkan biji dari masing-masing posisi dalam buah dimasukkan dalam kantong plastik polypropylen (PP) dan diberi label yang menunjukkan posisinya, dan kemudian disimpan pada kondisi ruangan (ambient room temperature). Benihbenih tersebut merupakan bahan dalam penelitian ini.

\section{Perlakuan dan Desain Percobaan}

Penelitian terdiri atas dua tahapan percobaan, yaitu tahap pertama bertujuan mengetahui viabilitas biji dari tiga posisi biji dalam buah (biji) dan tahap kedua bertujuan mengetahui pertumbuhan bibit tanaman kelor hingga umur dua bulan dari masing-masing posisi biji pada buah tersebut.

Percobaan diatur menurut Rancangan Acak Lengkap, dengan tiga perlakuan posisi biji dalam buah yaitu biji pada bagian pangkal buah, biji pada bagian tengah buah, dan biji pada bagian ujung buah. Uji viabilitas biji dilakukan pada bak plastik berukuran $45 \mathrm{~cm}$ x $25 \mathrm{~cm}$ x $10 \mathrm{~cm}$ ) berisikan media perkecambahan berupa campuran tanah-pasir-arang sekam (1:1:1 v/v) dibuat masing-masing lima ulangan, dan setiap ulangan terdiri atas 100 biji. Kecambah normal yang dihasilkan dari masing-masing lot pengujian viabilitas benih tersebut kemudian ditanam sebagai percobaan kedua pada polibag hitam (berukuran $15 \mathrm{~cm}$ x $25 \mathrm{~cm}$ ) sejumlah lima ulangan dan masing-masing ulangan terdiri atas lima belas polibag bibit. Media pembibitan dalam polybag berupa campuran tanah-kompos serasah daun bambu (1:1 v/v). 


\section{Pemeliharaan Bibit dan Pengamatan}

Perkecambahan dan pembibitan dilakukan di bawah naungan paranet hitam dengan penyiraman secara manual setiap dua hari sekali. Setelah dua minggu pindah tanam semai ke polibag, bibit dipupuk dengan 5 g NPK (15-15-15) setiap polibag. Bibit dipelihara selama dua bulan dari sejak pindah tanam.

Penilaian bobot benih (biji). Sebanyak 10 sampel sejumlah 100 biji ditimbang untuk masing-masing ulangan. Pengukuran bobot menggunakan timbangan elektronik sensitif $(0,01$ mg) (merek OHAUS Precision Plus).

Perkecambahan biji. Dari setiap unit 100 biji yang dikecambahkan pada bak berukuran 45 $\mathrm{cm} \times 25 \mathrm{~cm} \times 10 \mathrm{~cm}$ ) diamati selama 21 hari terhadap daya kecambah, laju perkecambahan, dan jumlah kecambah normal. Komponen viabilitas biji tersebut dihitung dengan menggunakan rumus sebagai berikut,

Daya kecambah $=\frac{\sum \text { benih yang berkecambah }}{\sum \text { benih yang dikecambahkan }} \times 100 \%$

Laju perkecambahan $=\frac{\Sigma \text { benih yg berkecambah }}{\Sigma \text { hari yang uji }}$

Pertumbuhan bibit. Variabel pertumbuhan bibit dalam polibag yang dievaluasi meliputi tinggi bibit, diameter batang bibit, jumlah daun bibit, dan berat kering berangkasan setiap satu bulan sekali.

\section{Analisis Data.}

Data dianalisis dengan Anova pada tingkat kepercayaan 5\% dan standar deviasi dari rata-rata nilai tiap variable viabilitas benih dan pertumbuhan bibit dengan menggunakan merangkat lunak Minitab-14.

\section{HASIL DAN PEMBAHASAN}

Benih dapat berkecambah dan tumbuh dengan cepat karena adanya mekanisme yang sebagian besar dipengaruhi oleh faktor dalam dan faktor luar. Faktor dalam sangat tergantung pada kondisi benih itu sendiri seperti tingkat kemasakan dan ukuran benih, sedangkan faktor luar adalah lingkungan yang sesuai untuk proses perkecambahan tersebut.

Daya berkecambah menggambarkan kemampuan benih untuk tumbuh dan berkembang menjadi tanaman pada kondisi optimum, sedangkan kecambah normal dan juga bobot kering kecambah normal merupakan tolok ukur viabilitas potensial yang menggambarkan banyaknya cadangan makanan yang tersedia sehingga bila dikondisikan pada lingkungan yang sesuai mampu tumbuh dan berkembang dengan baik.

Hasil penelitian menunjukkan bahwa terdapat perbedaan nyata viabilitas biji yang berasal dari tiga posisi biji dalam buah pada tingkat kepercayaan $\mathrm{p}=0,05$ (Tabel 1). Namun tidak ada perbedaan nyata ketiga posisi biji dalam buah kelor tersebut pada variabel pertumbuhan bibit hingga berumur dua bulan (Tabel 2). 
Tabel 1. Viabilitas biji kelor dari tiga posisi biji dalam buah

\begin{tabular}{lcccc}
\hline $\begin{array}{c}\text { Posisi } \\
\text { Biji }\end{array}$ & $\begin{array}{c}\text { Bobot } \\
\mathbf{1 0 0 ~ B i j i} \\
(\mathbf{g})\end{array}$ & $\begin{array}{c}\text { Daya } \\
\text { Kecambah } \\
(\mathbf{\%})\end{array}$ & $\begin{array}{c}\text { Kecepatan } \\
\text { Berkecambah } \\
(\mathbf{h r})\end{array}$ & $\begin{array}{c}\text { Kecambah } \\
\text { Normal } \\
(\boldsymbol{\%})\end{array}$ \\
\hline Ujung & $17,3 \pm 2,53 \mathrm{~b}$ & $51,12 \pm 14,33 \mathrm{~b}$ & $8,3 \pm 1,12 \mathrm{~b}$ & $59,91 \pm 5,54 \mathrm{~b}$ \\
Tengah & $20,1 \pm 1,11 \mathrm{a}$ & $82,58 \pm 7,79 \mathrm{a}$ & $6,9 \pm 1,08 \mathrm{ab}$ & $83,35 \pm 2,98 \mathrm{a}$ \\
Pangkal & $21,6 \pm 0,86 \mathrm{a}$ & $71,23 \pm 9,25 \mathrm{a}$ & $6,5 \pm 1,09 \mathrm{a}$ & $79,87 \pm 3,43 \mathrm{a}$ \\
\hline LSD 5\% & 2,21 & 15,87 & 1,24 & 17,79
\end{tabular}

Keterangan: angka-angka pada masing-msing kolom yang diikuti huruf yang sama berbeda tidak nyata menurut LSD 5\%

Tabel 2. Pertumbuhan bibit kelor dari tiga posisi biji dalam buah

\begin{tabular}{lcccccccc}
\hline \multirow{2}{*}{$\begin{array}{c}\text { Posisi } \\
\text { Biji }\end{array}$} & \multicolumn{2}{c}{$\begin{array}{c}\text { Tinggi } \\
\text { Bibit } \\
(\mathbf{c m})\end{array}$} & \multicolumn{2}{c}{$\begin{array}{c}\text { Jumlah } \\
\text { Daun } \\
\text { (helai) }\end{array}$} & \multicolumn{2}{c}{$\begin{array}{c}\text { Diameter } \\
\text { Batang } \\
(\mathbf{m m})\end{array}$} & \multicolumn{2}{c}{$\begin{array}{c}\text { Bobot Kering } \\
\text { Bibit } \\
\text { (g) }\end{array}$} \\
\cline { 2 - 10 } & $\mathbf{3 0 ~ h s t}$ & $\mathbf{6 0}$ hst & $\mathbf{3 0}$ hst & $\mathbf{6 0}$ hst & $\mathbf{3 0}$ hst & $\mathbf{6 0}$ hst & 30 hst & $\mathbf{6 0 ~ h s t}$ \\
\hline Ujung & 21,1 & 58,8 & 8,9 & 13,8 & 0,2 & 0,6 & 1,64 & 6,71 \\
Tengah & 20,9 & 57,2 & 8,5 & 12,2 & 0,3 & 0,6 & 1,44 & 6,52 \\
Pangkal & 20,6 & 56,5 & 8,7 & 13,3 & 0,2 & 0,5 & 1,29 & 5,89 \\
\hline LSD 5\% & - & - & - & - & - & - & - & - \\
\hline
\end{tabular}

Berpengaruh nyata posisi biji dalam buah terhadap viabilitas biji disebabkan adanya perbedaan kualitas nutrisi biji tersebut. Persaingan antara biji di dalam buah kelor terhadap kebutuhan nutrisi selama pertumbuhan dan perkembangan buah menghasilkan perbedaan nutrisi terkandung pada masing-masing biji pada masing-masing posisi dalam buah.

Biji pada posisi pangkal dan tengah tampak memiliki peluang lebih baik untuk mendapatkan nutrisi, sehingga pada akhirnya akan memiliki viabilitas biji yang lebih baik dibandingkan biji-biji pada posisi ujung. Peneliti pada kesempatan ini mendapatkan bahwa buah kelor merupakan buah dengan kejadian pemasakan fisiologis yang dimulai dari pangkal buah, sehingga akumulai nutrisi dari tanaman induk ke buah lebih banyak terjadi pada buah di posisi pangkal buah hingga posisi tengah buah. Jadi, pemasakan buah sekaligus biji yang ada di dalamnya terjadi fenomena bahwa biji-biji yang posisinya di pangkal lebih dahulu masak dan kemudian secara bertahap menuju ke posisi tengah dan akhirnya posisi ujung.

Pada penelitian ini dijumpai bahwa bobot segar buah ( $p o d$ ) dan biji (seed) mengalami perubahan (perkembangan) selama proses pematangan (maturation), pemasakan (ripening), dan penuaan (senescence). Buah dan biji mengalami peningkatan bobot secara nyata hingga buah mencapai kondisi masak yang dicirikan buah sebagian telah mengalami perubahan warna menjadi coklat atau buah mulai mengering, dan setelah tahapan tersebut biji maupun buah mengalami menurununan bobot secara perlahan. Fenomena ini terjadi pula pada buah jarak pagar yang dilaporkan Santoso et al. (2012), bahwa biomassa buah dan biji yang ada di dalamnya mengalami perubahan bobot seiring dengan perkembangan buah, dan hal tersebut dikarenakan tingginya kandungan air di saat tahapan pematangan dan mulai mengalami pengurangan kandungan air pada saat tahapan pemasakan. Sadjad et al. (1999) selanjutnya menyatakan bahwa, perubahan tersebut tentunya akan mempengaruhi perubahan metabolisme dalam biji yang kemudian akan mempengaruhi komponen isi bahan kering dalam biji sehingga pada akhirnya mempengaruhi viabilitas biji tersebut. 
Selain stadia kemasakan buah, letak biji pada buah juga mempengaruhi viabilitas benih. Biji yang letaknya pada bagian tengah dari buah, mempunyai ukuran lebih besar dan lebih homogen dari pada biji yang letaknya pada bagian ujung dan pangkal buah. Beberapa hasil penelitian terkait posisi biji dan juga posisi buah pada tanaman menunjukkan, bahwa benih bermutu baik adalah benih yang berukuran sedang dan seragam, benih-benih tersebut biasanya diperoleh dari biji yang posisinya di pangkal buah. Selanjutnya dikatakan bahwa benih yang terletak pada bagian ujung buah mempunyai viabilitas rendah, karena mempunyai cadangan makanan lebih sedikit dibandingkan dengan benih yang terletak di tengah (Nouman et al., 2012). Selain itu benih yang terletak di bagian ujung buah mempunyai selaput pelindung yang sangat tipis, sehingga sangat peka terhadap serangan penyakit dan kekeringan (Palada and Chang, 2003).

Bahwasannya seiring dengan pertumbuhan dan perkembangan buah dan juga biji yang ada di dalamnya, maka terjadi pula perubahan-perubahan komposisi penyusun (isi) biji bersangkutan. Perubahan tersebut tentunya dipengaruhi oleh factor lingkungan, dan genetik, dan juga tahapan kematangan biji. Seperti dikatakan oleh Rahmatalla et al. (2001) dan Bhardwaj and Hamama (2003) bahwa pada biji berminyak, kandungan minyak (lemak) mengalami perubahan sesuai dengan lama waktu perkembangannya.

Kemasakan benih pada kelor ditandai dengan perubahan warna benih menjadi cokelat mulai dari bagian pangkal buah bunga. Hal ini sejalan dengan pendapat Munir (2013) bahwa periode masak fisiologi dapat ditunjukkan dengan adanya perubahan warna morfologi buah/biji. Penelitian Sutardi dan Hendrata (2009) menunjukkan bahwa letak biji dalam buah kakao berpengaruh nyata terhadap pertumbuhan tanaman kakao yang dihasilkan. Biji kakao yang terletak pada bagian tengah buah memiliki ukuran yang relatif lebih besar, hal ini menunjukkan bahwa cadangan makanan atau nutrisi yang terkandung pada biji bagian tengah lebih banyak. Demikian pula Santoso et al. (2012) mengatakan bahwa tingkat kematangan yang baik bagi diperolehnya biji jarak pagar berviabilitas tinggi adalah pada buah yang telah berwarna kuning dan mulai mengering.

\section{KESIMPULAN}

Biji-biji yang berada pada posisi pangkal dan tengah pada buah kelor memiliki viabilitas lebih baik dibandingkan biji berposisi di ujung buah. Perbedaan posisi biji pada buah berpengaruh tidak nyata terhadap pertumbuhan bibit kelor. Dalam rangka mempersiapkan benih berkualitas pada usaha pengembangan tanaman kelor, maka biji-biji yang berposisi di pangkal dan posisi di tengah buah kelor dapat digunakan sebagai sumber benih.

\section{Ucapan Terimakasih}

Peneliti mengucapkan terima kasih kepada Kemenristekdikti atas dana yang diberikan melalui penelitian skim Penelitian Terapan Unggulan Perguruan Tinggi tahun 2017 dengan nomor kontrak 074/SP2H/LT/DRPM/IV/2017.

\section{DAFTAR PUSTAKA}

Anwar, F., Latif, S., Ashraf, M. and Gilani, A.H., 2007. Moringa oleifera: A food plant with multiple medicinal uses. Phytother. Res. 21: 17-25. 
Bayé-Niwah, C. and Mapongmetsem, P.M. 2014. Seed germination and initial growth in Moringa oleifera Lam. 1785 (Moringaceae) in Sudano-Sahelian zone. International Research of Plant Science (ISSN: 2141-5447). 5(2):23-29. DOI: http:/dx.doi.org/10.14303/irjps.2014.018

Bhardwaj, H.L. and A.A. Hamama. 2003. Accumulation of glucosinolate, oil, and eruric acid in developing Brassica seeds. Ind. Crops. Prod. 17:47-51

Branco, L.M. 2007. Pengaruh pemangkasan pohon dan letak benih dalam buah terhadap peningkatan produksi dan mutu benih papaya (Carica papaya L.). Tesis Program Studi Agronomi Sekolah Pascasarjana IPB, Bogor.

Fahey, JW. 2005. Moringa oleifera: A Review of the medical evidence for its nutritional, therapeutic, and prophylactic properties. Part1. Trees for Life J.1(5).

Foidl N., Makkar H., Becker K. 2001. The miracle tree. The multiple uses of Moringa. Wagening. Netherlands. p:45-76

Mapongmetsem, PM., Duguma, B., Nkongmeneck, BA., and Selegny, E. 1999. The effect of various seed pretreatments to improve germination in eight indigenous tree species in the forest of Cameroon. Ann. Sci. Forest, 56: 679-684.

Marliah, A., Imran, S., Alkausar, 2009. Viabilitas benih nangka (Artocarpus heterophyllus Lmk.) pada berbagai stadia kemasakan dan letak biji. J. Floratek 4: 65-72

Mubvuma, M. T., Mapanda ,S., and Mashonjowa, E. 2013. Effect of storage temperature and duration on germination of moringa seeds (Moringa oleifera). Greener J. of Agricultural Sciences. 3(5):427-432.

Muluvi G. M., Sprent J.I., Soranzo., Provan J., Odee D., Folkard D., Mcnicol J.W., Powell W. 2013. Amplified fragment length polymorphysm analisis of genetic variation in Moringa oliefera Lam. J. of Molecular Ecology. 8: 463-470.

Munir B. 2013. Analisis keragaan pengaruh tingkat kemasakan terhadap daya berkecambah benih jarak pagar (Jatropa curcas L.). http:// ditjenbun. pertanian. go. id/bbpptpsurabaya/tinymcpuk/gambar/file/Analisis_20Keragaan_20Tingkat_20Kemasa kan_20Buah_20Web.pdf. [Mei 2017]

Nouman, W., Siddiqui, MT., Basra, SMA., Afzal, I., Rehman, H. 2012. Enhancement of emergence potential and stand establishment of Moringa oleifera Lam. by seed priming. Turk. J. Agric. For. 36: 227-235.

Palada, MC, and Chang, LC. 2003. Suggested cultural practices for Moringa. International Cooperators'Guide. AVRCD.5p

Prajapati, R.D., Murdia, P.C., Yadav, C.M., Chaudhary, J.L. 2003. Nutritive value of drumstick (Moringa oleifera) leaves in sheep and goats. Indian J. of Small Ruminants (2):136-137.

Rahmatalla, A.B., E.E. Babiker, A/G. Krishna, A.H. El Tinay. 2001. Change in fatty acids composition during growth and physicochemical characteristics of oil extracted from four Safflower cultivars. Plant Food Hum. Nutr. 56: 385-395.

Rashid, U., Anwar, F., Moser, B.R. and Knothe, G. 2008. Moringa oleifera oil: A possible source of biodiesel. Bioresource Technology. 99: 8175-8179.

Sadjad, S., Murniati, E., Ilyas, S. 1999. Parameter pengujian vigor benih. Jakarta (ID): PT Grasindo. 
Santoso, B.B., Budianto, A., Arayana, IGPM. 2012. Seed viability of Jatropha curcas in different fruit maturity stages after storage. Nusantara Bioscience. 4(3): 113-117. DOI: \&\#13;10.13057/nusbiosci/n040305

Sulistyowati, H. 2004. Perbaikan mutu benih pepaya (Carica papaya. L) dengan menggunakan mesin pemilah benih. Skripsi. Bogor. Departemen Budidaya Pertanian. Faperta. IPB. 56 hal.

Sutardi dan Hendrata, R. 2009. Respon bibit kakao pada bagian pangkal, tengah, dan pucuk terhadap pemupukan majemuk. Agrivigor. 2(2):103-109. 